\title{
THE EFFECT OF USING FLIPPED TEACHING IN PROJECT MANAGEMENT CLASS FOR UNDERGRADUATE STUDENTS
}

\author{
Mohammed F.M. Abushammala
}

Department of Civil Engineering, Middle East College (Sultanate of Oman)

mabushammala@mec.edu.om

\begin{abstract}
Received September 2018
Accepted December 2018
\end{abstract}

\section{Abstract}

Teaching Project Management module to undergraduate students is important and has been globally considered in multiple academic disciplines by many higher institutions. Students in undergraduate level encounter difficulty in understanding the topic of project management since there have no prior knowledge before the course. This paper aimed to determine the effectiveness of flipped teaching and active learning in Project Management module for undergraduate students in Civil Engineering. However, the paper discussed the effective practices in teaching and learning project management and their impacts into students' learning experience, and assessments development and marking. The Padlet and SurveyMonkey e-tools were used to collect students' feedback on the instructor practice; either by tagging comments or filling questionnaire. The results indicated that the use of multiple in-class activities and digital technology in a flipped classroom are important to enhance students' performance. It is also observed that the use of multiple assessments engaged students deeply with the course and provide deeper learning. Students' performance in summative assessments showed that there is a noticeable improve in student's scores in the current semester in contrast with previous semester where traditional teaching was practiced.

Keywords - Flipped teaching, Active learning, Project management, Classroom activities, Teaching and learning.

\section{To cite this article:}

Abushammala, M.F.M. (2019). The effect of using flipped teaching in project management class for undergraduate students. Journal of Technology and Science Education, 9(1), 41-50.

https://doi.org/10.3926/jotse.539

\section{Introduction}

The importance of teaching Project Management course have been recognized by various professional bodies and researchers (Hussein, 2015). Therefore, teaching Project Management module for undergraduate students is important and has been globally considered in multiple academic disciplines by many higher institutions. It is prepared students to deal with different complex projects as reported by Ramazani and Jergeas (2015). The urgency, uncertainty, ambiguity, complexity and uniqueness are projects characteristics (Kalimullina, Yungbludb \& Khodyreva, 2016), which need to be discussed with active approach rather than depending only on the theoretical approach. Therefore, it is important that 
instructors adopt learning aids and teaching approaches that invert the learning process from passive into active process.

Students in undergraduate level encounter difficulty in understanding the topic of Project Management module since there have no previous experience before the course, thus, they cannot use their former knowledge and skills. Accordingly, the use of suitable pedagogics approaches is important in order to ensure a success learning process. According to Kolesnikova (2016), a combination of different pedagogical approaches and learning approaches could be considered by instructors to improve the process of teaching and learning. This was consistent with Hussein (2015) who found that the use of different teaching and learning methods, in particular, in class gaming was contributed to students learning experience. The use of classroom lectures together with technology-based methods was defined by Lalima and Dangwal (2017) as blended learning, where students are experienced learning in various comfortable ways. According to Slomanson (2014), students taught in a blended method shown an average of $35 \%$ stronger learning outcomes in contrast to those learned by face-to-face teaching.

Flipped learning method means that the students' learning activities are flipped (Bergmann \& Sams, 2013). In flipped learning method, student in out-classroom activities read and understand the content outside classroom and teach inside classroom. There are many studies revealed that flipped learning is very effective method for enhancing students' learning (Arnold-Garza, 2014; Slomanson, 2014). According to Kim, Heo and Lee (2015), the use of flipped learning improves students' self-awareness and skills of undergraduate students of Korean University and invert them from passive to active students with enough interaction with teacher at class. On the other hand, the same authors found that the used of flipped learning method in teaching Project Management course improved students' understanding on the topics and create more active discussion.

Traditional teaching of Project Management module was practiced previously in Civil Engineering Department, Middle East College (MEC), Oman, where the teacher caused learning and control the learning environment; the teacher was active and students were passive. In order to turn students from passive learners to active learner (Student-Centric Teaching), the flipped learning method have been adopted in teaching Project Management module as a part of MEC's teaching and learning strategic approach, which improve students' capabilities such as problem solving, critical thinking, and soft skills. Furthermore, the use of flipped learning method motivates students to participate in learning process and increases group work (Roach, 2014).

The aim of this paper is to determine the effectiveness of flipped teaching and active learning in Project Management module for undergraduate students in civil engineering. Furthermore, the paper discussed the effective practices in teaching and learning Project Management, and their impacts into students' learning experience. Flipped teaching method with several instructional methods such as supporting materials, lecture notes, use of Information and Communication Technologies (ICT) tools, recorded videos, classroom activities, written reports, exercises and formative assessments, and quizzes have been used in this course to ensure effective learning.

\section{Approach}

\subsection{Teaching, Learning and Classroom Practice}

The Project Management module was chosen for the current study, the number of students involved was 25. The module includes theory and computer laboratory sessions. Kistner, Rakoczy, Otto, Klieme and Büttner (2015) reported that the use of various teaching techniques enhanced skills development. Therefore, conceptual delivery of the Project Management module included flipped teaching combined with active learning during class session (theory), and a combination of theoretical lecture and active learning was adopted in the computer lab (lab session) following Othman, Pislaru and Impes (2014). Constructivist pedagogical approach was predominated in the teaching and learning the course, where students construct their own understanding and knowledge, and the instructor as facilitator (Bhattacharjee, 2015). 
The design of a flipped classroom requires more consideration on the structure and content of the module. During the theory session, in a flipped classroom where the teacher-centered (content) method was inverted to student-centered (learning) method, the students engaged with various activities divided into before-class, in-class, and after-class activities (Bishop \& Verleger, 2013). Before class activities included lecture, materials and recorded short videos uploaded to the students using the colleges' Moodle at least one week in advance to prepare for an active learning in-class. According to O'Flaherty and Phillips (2015), out-class videos increase in-class time for engaging students in learning activities. The in-class activities included group discussion, Think-Pair-Share, peer teaching, presentation, groups' competition, and quizzes to provide deeper learning.

There are different e-tools available that can be utilized in teaching and learning, these include Socrative, Kahoot, Screencast-O-Matic, Padlet, AnswerGarden, SurveyMonkey, VideoPad, Wordle, and many more. Different digital technologies have been used to improve students' learning of Project Management module. The "Screencast-O-Matic" and "VideoPad" were used in the module under the study to record and edit videos. The YouTube was used to select videos or to upload recorded videos prepared by the instructor. According to Kolås (2015), the use of interactive videos creates active learning experience, and enhance students' performance. Therefore, interactive tools such as Vizia and PlayPosit were used to add some questions to those videos for the students to complete, and thus, engage students deeply with the videos and overcome the problem of a smaller number of viewers before class where these tools required student's information for registration such as student's name and email ID (Figure 1). From students' answers on those questions, it was observed that students unequally benefit (Figure 1), and thus, group and individual activities (scaffolding) have been adopted to enhance their learning styles following the Zone of Proximal Development theory (Shabani, Khatib \& Ebadi, 2010). These interactive tools enabled the instructor to well organise group members during class with at least one student who have watched the videos. The in-class activities were usually disconnected every 15 minutes by brisk exercise to maintain students' attention. The instructor also preserved to not talk continuously more than 20 minutes during class following Bradbury (2016).

Repetitive Projects_1
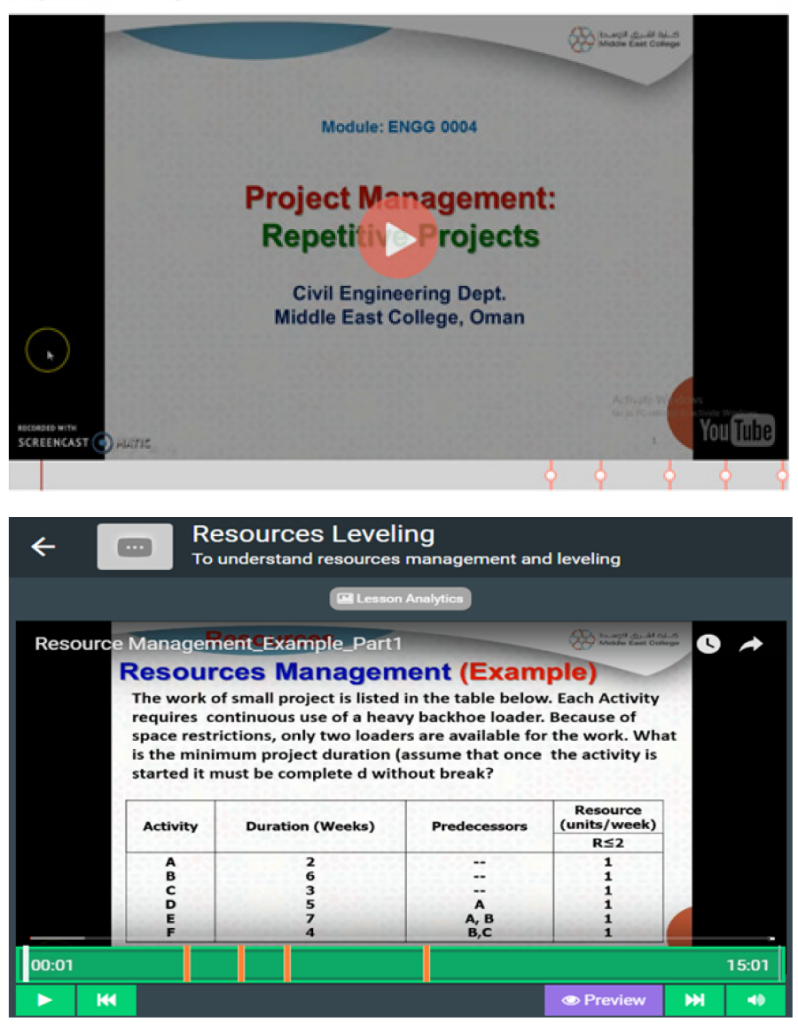

Q4 in Formtive Assessment_3_Part1
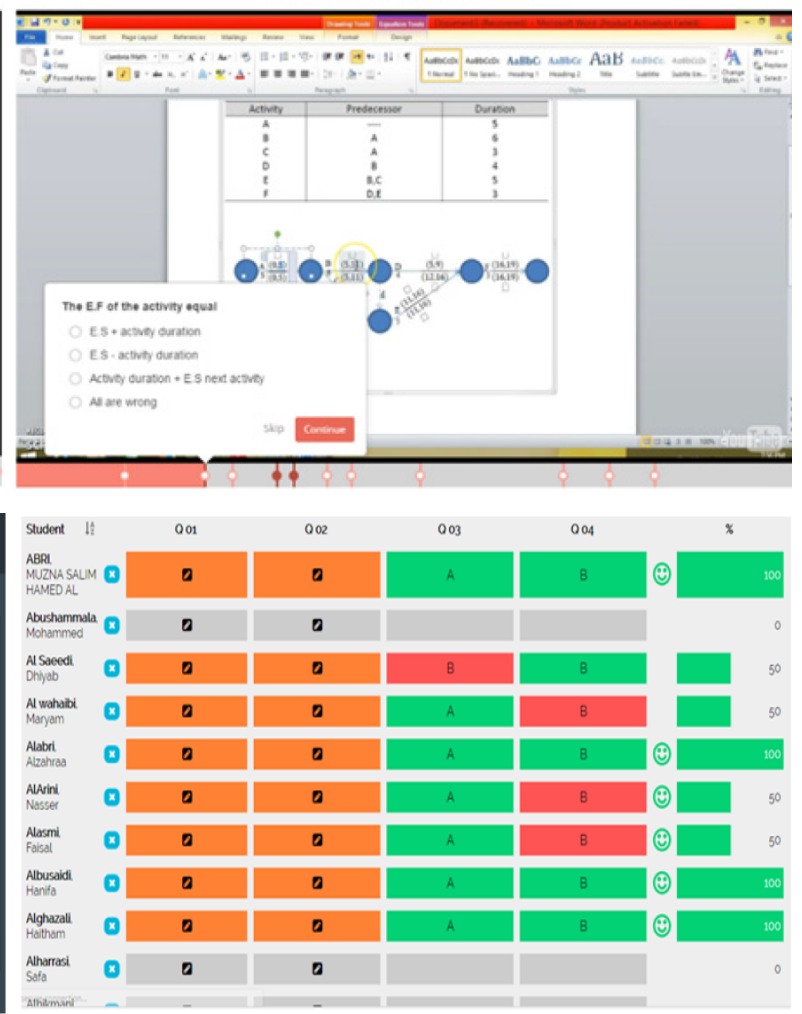

Figure 1. Out-class videos using Vizia and PlayPosit interactive tools 
Different approached have been utilized to make learning more effective during lab sessions, these included providing short videos from the YouTube, and the use of a combination of theoretical lecture and interactive activities such as peer teaching following Lim (2014) as shown in Figure 2.
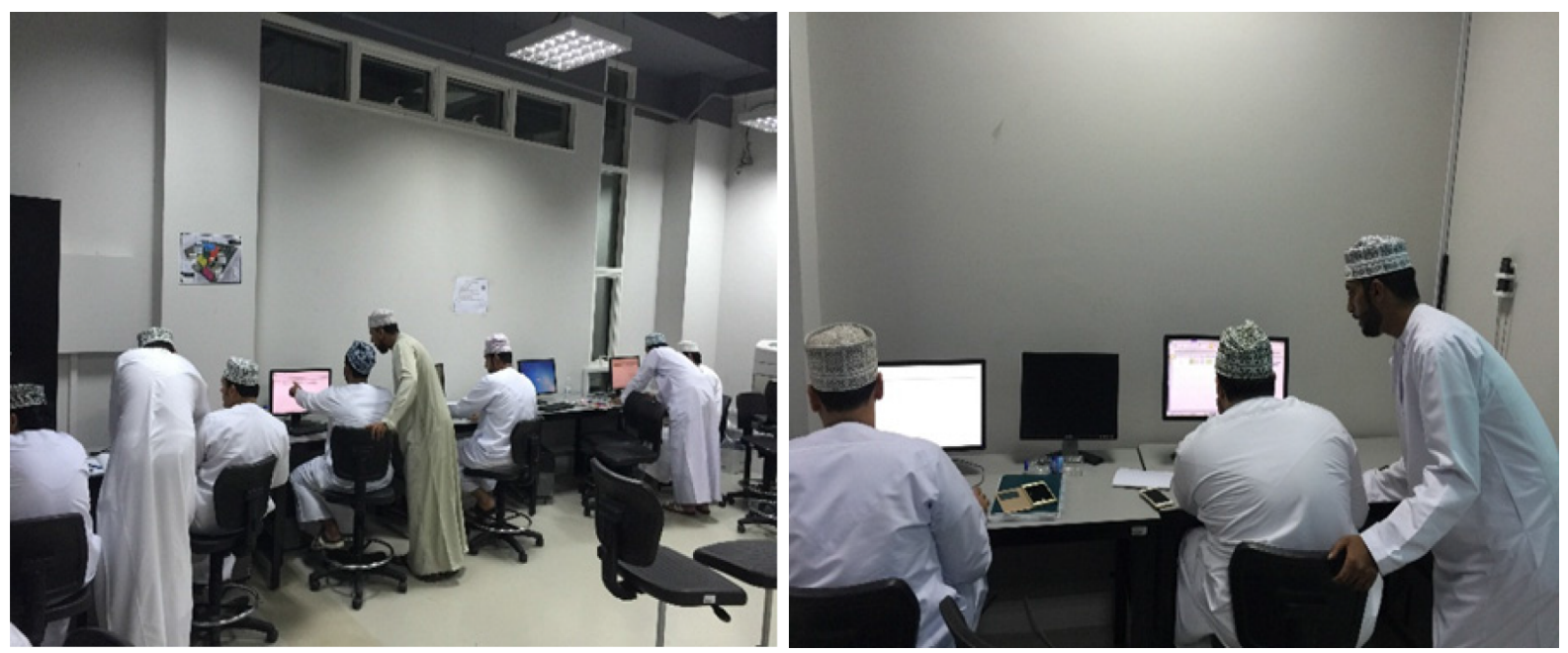

Figure 2. Peer teaching activity in laboratory session

\subsection{Assessments Development}

\subsubsection{Formative Assessment}

Formative assessments have been used to observe individual learning capability and to check the effectiveness of learning, and also ensured that constructive feedback and feedforward for individual students are provided on time as per the MEC's Assessment Policy. According to Kulasegaram and Rangachari (2018), the use of formative assessment enhances and enrich students learning and performance. In the classroom, Socrative tool and mobile devices were used to conduct online quizzes to measure overall students' performance and the effectiveness of teaching and learning.

\subsubsection{Summative Assessment}

Three summative assessments were prepared to assess students in Project Management module; laboratory reports, final project, and end semester examination. According to the module descriptor, the laboratory reports and final project weightage $50 \%$, while the end semester examination weightage $50 \%$.

\subsubsection{Coursework Preparation}

The coursework assessment which included laboratory reports and final project have been prepared to simulate real work projects. This was consistent with Collingbourne and Seah (2015: page 1) who stated that "Effective pedagogy for project management requires students to get real-world experience".

According to Anney and Mosha (2015), plagiarism is a general problem among undergraduate students in higher institutions. Therefore, and to overcome the problem of plagiarism, an excel sheet was designed and provided to the students with an individual data to be used in both lab reports and final project coursework (Figure 3). This practice was effective and ensured compliance with the MEC's Student Academic Integrity Policy, where very fewer plagiarism cases have been observed in contrast with previous semesters.

According to Gary and Min (2017), the use of technology facilitates the presentation of assessment tasks to students. Accordingly, the Xmind tool has been used in the presentation of coursework assessment, and students were requested to use it in their final project presentation (Figure 4). One key observation 
emerging from the use of this tool that students can generate new ideas and enhance the level of understanding of their assessment.

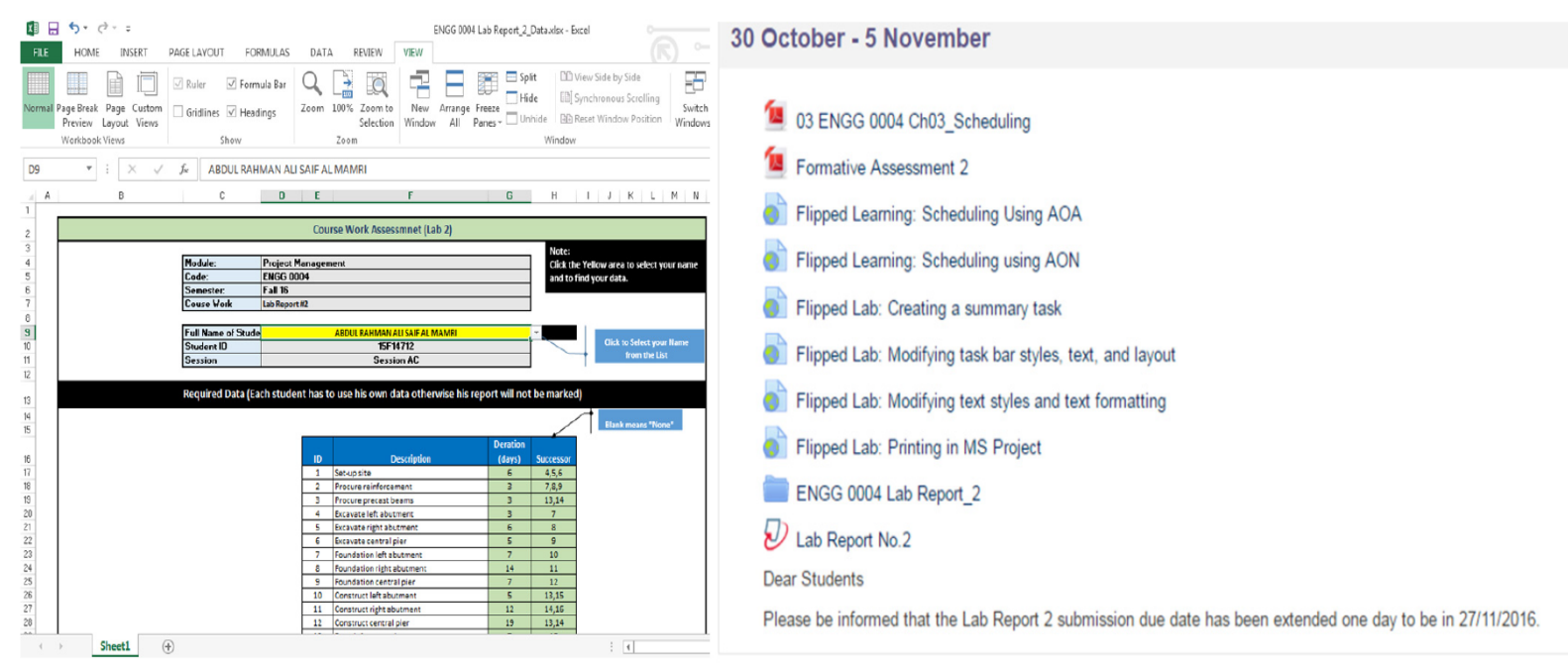

Figure 3. The use of individual data and turn-it-in software to check plagiarism percentage

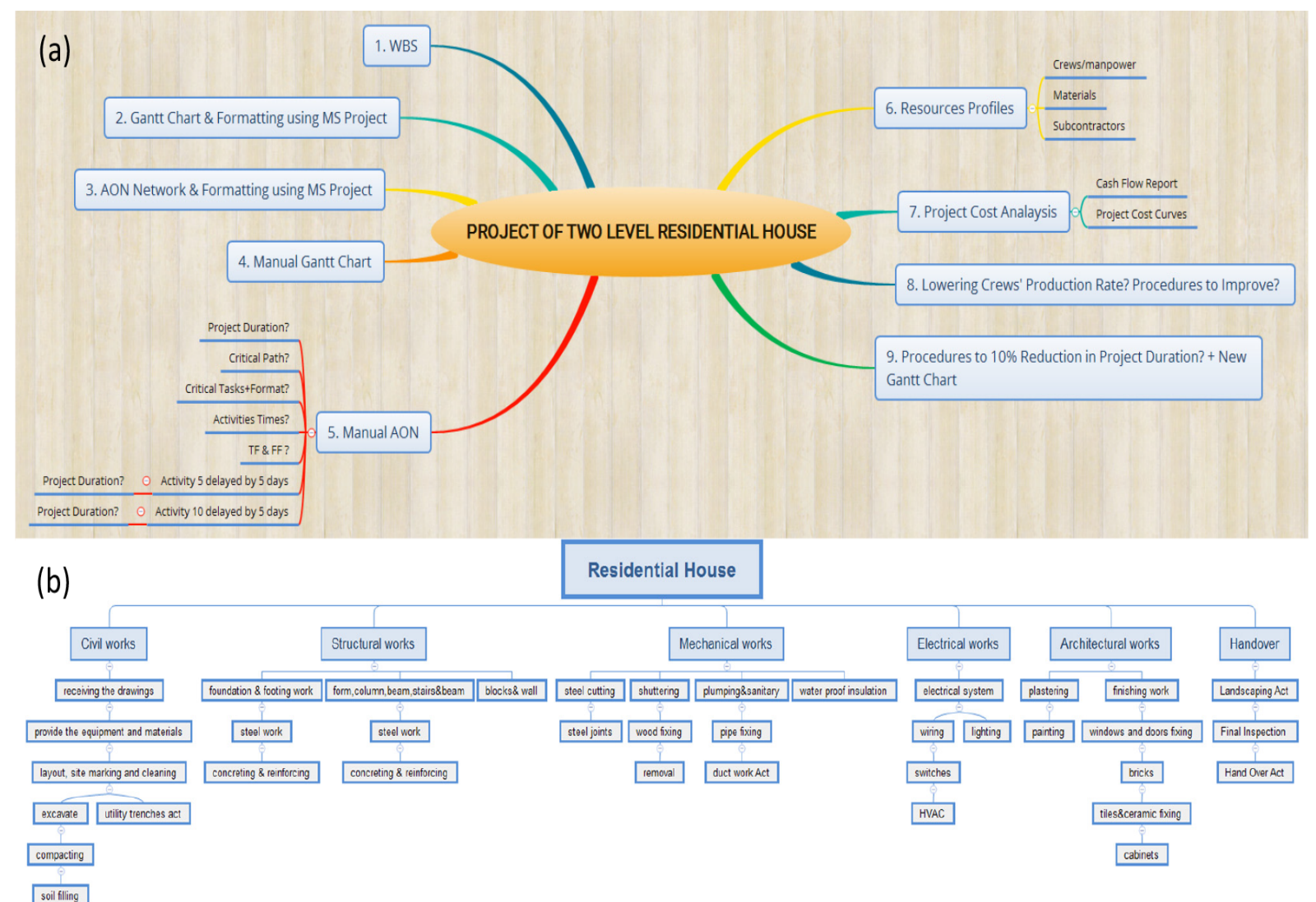

Figure 4. Examples of using the Xmind tool in coursework; a) faculty work, and b) students' work

\subsubsection{End Semester Exam}

The formative assessments have been linked to the end semester exam during classroom discussion in order to attract students' attention. The Constructive Alignment principle have been considered in designing the end semester exam following Biggs and Tang (2011); where teaching and learning activities, module's learning outcomes, and the end semester and coursework assessments are related to each other. 
Furthermore, the Bloom's Taxonomy have been used for preparing end semester and coursework question papers.

\subsubsection{Assessment and Marking}

The use of 6-principles of marking and grading (Fry, Ketteridge \& Marshall, 2009) was predominated during the marking process which positively changed the instructor practice and ensured implementation of standards in the MEC with respect to grading process. Students' performance in summative assessments showed that there is a noticeable increase of approximately $11.6 \%$ in student's scores in the current semester in contrast with previous semester where traditional teaching was practiced (Table 1).

\begin{tabular}{|l|r|r|}
\hline \multicolumn{1}{|c|}{ Statistics } & Previous Semester & \multicolumn{1}{c|}{ Current Semester } \\
\hline Coursework Mean & 35.21 & 38.24 \\
\hline End Semester Mean & 28.23 & 32.53 \\
\hline Total Mean & 63.44 & 70.77 \\
\hline Standard Deviation & 13.12 & 11.71 \\
\hline
\end{tabular}

Table 1. Student scores during previous and current semesters

\section{Students' Feedback and Performance}

Feedback is well-established as a crucial aspect of successful teaching and learning. The Padlet and SurveyMonkey e-tools were used to collect students' feedback on the instructor practice; either by tagging comments or filling questionnaire. However, the instructor's feedback on the formative assessments was provided instantly after the submission, through email, on paper or verbally, Moodle system of the college, and sometimes accidentally. Similarly, the feedback on summative coursework assessments was provided to the students within two weeks after their submission as per the MEC's Assessment Policy. Students' feedback generated by SurveyMonkey e-tool on classroom management activities is provided in Figures 5 and 6 . In general, the feedback from all the respondents showed appreciation of the practice and confirmed its effectiveness. Students' feedback shown that more than $90 \%$ of students agreed that the various classroom activities and classroom management enhanced the learning environment (Figure 5). It is also indicated that the group discussion in-class activity is the most desirable class activity among other classroom activities (Figure 6). In addition, students' responds indicated that active learning pedagogical activities influence students' satisfaction with their learning processes positively (Figure 6). It was found that the sources of satisfaction were the use of multiple in-class activities and digital technology in a flipped classroom and the use of multiple assessments which engaged students deeply with the course and provide deeper learning.

Through the continuous feedback collected from students on the teaching and learning practice such as classroom activities, production of video lectures, and other classroom activities, it was very easy to the module instructor to identify students' problems and misconceptions, and to reflect on each class using lesson plan in order to consider the learning objectives of certain activities being performed. However, the Module Evaluation Survey (MES) conducted by the MEC between weeks 9 and 12 each semester under Student Feedback Policy helps in review and evaluate the teaching and learning practices, and subsequently, reflection of the entire semester practices was performed using Module Review Form provided by the MEC in order to develop the professional practice and enhance the design of flipped classroom approach for the next semester. 
The teacher makes the subject interesting and conveys his enthusiasm for the subject-effect

Answered: 20 Skipped: 0

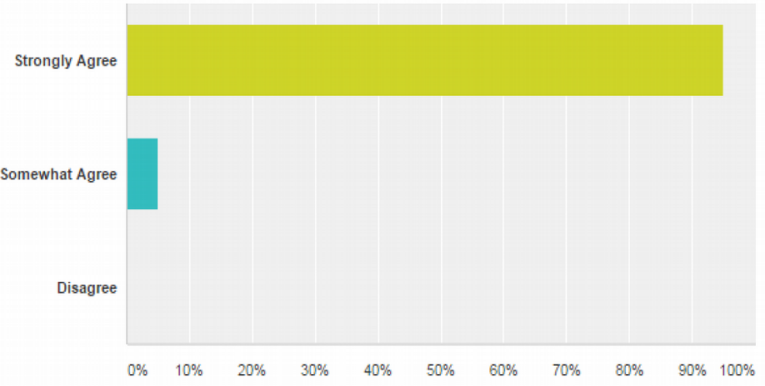

As a student I was given enough space and time to interact with my peers

Answered: 20 Skipped: 0

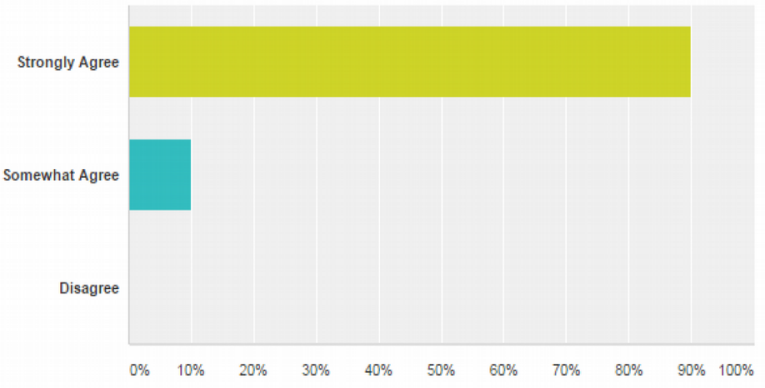

I understand the things clearly by doing activities in the class

Answered: 20 Skipped: 0

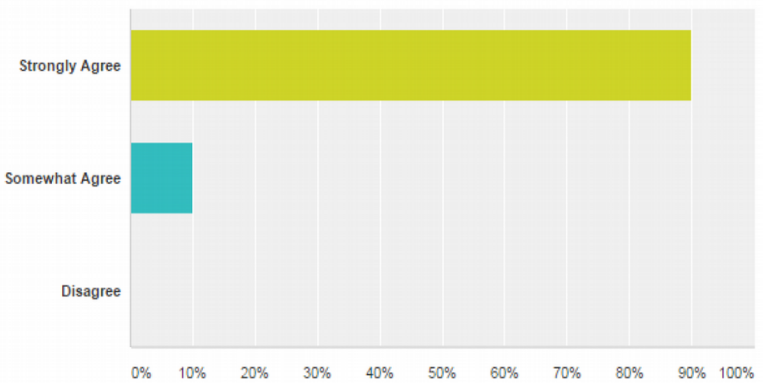

Who is usually talking more during class, I (teacher) or you (student)?

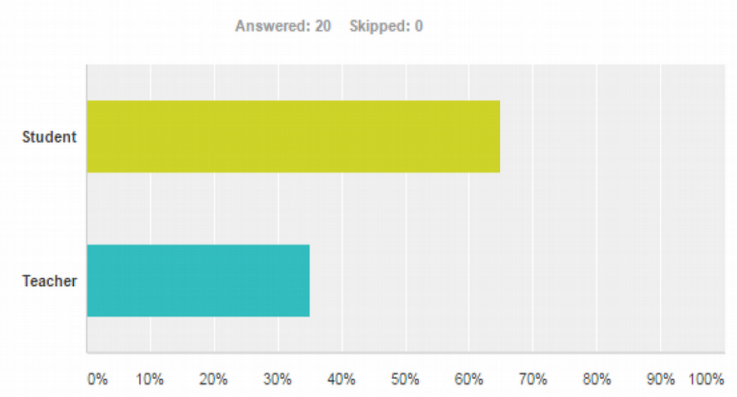

Do the teacher encourages students to ask questions and seek help

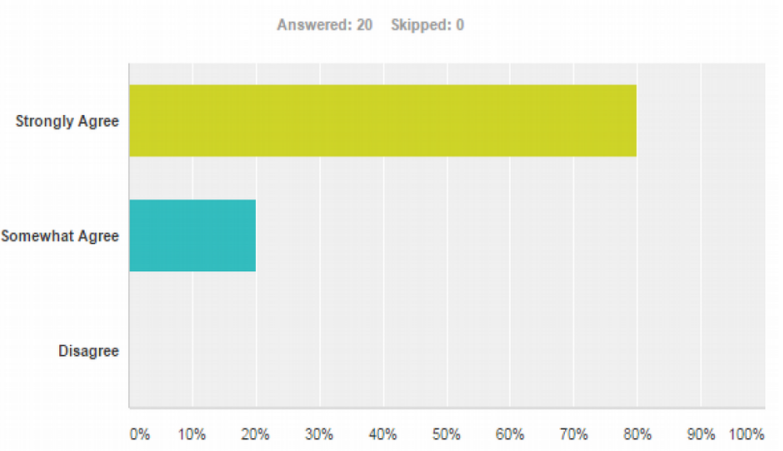

The grouping was properly organized

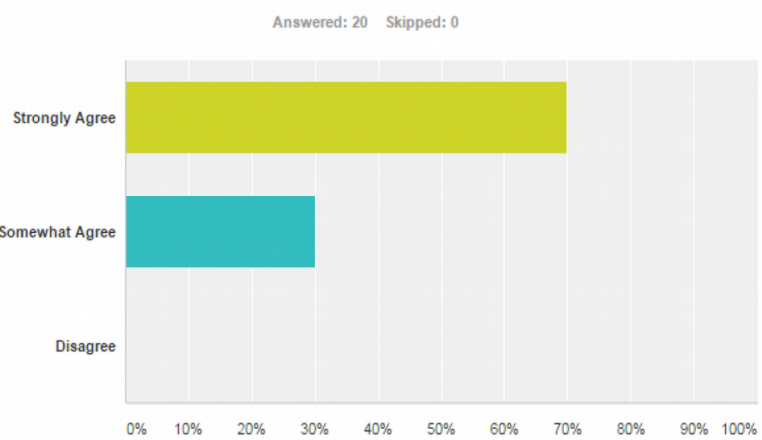

My engagement in the class is more when I am involved in various activities

Answered: 20 Skipped: 0

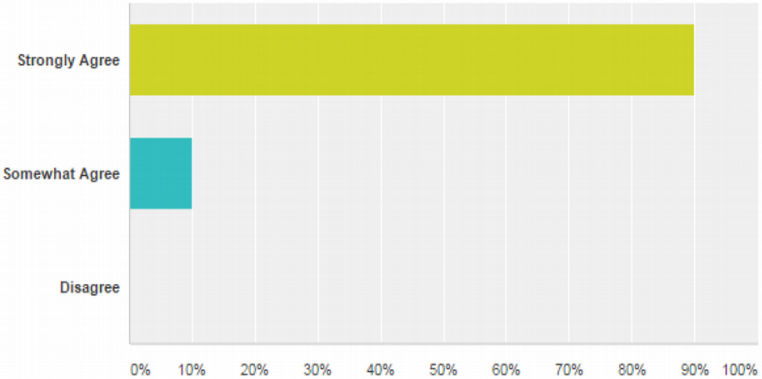

Activities in the class help me to check my level of understanding and to get help from teacher to have more clarity Answered: 20 Skipped: 0

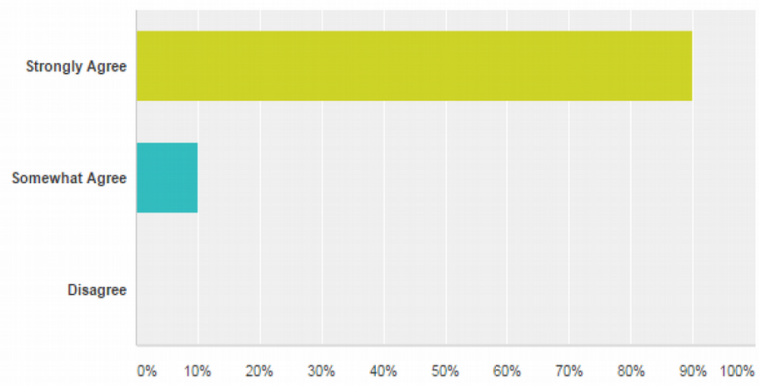

Figure 5. Example of students' feedback on classroom management and activities 
Did you like the lesson?

Answered: 25 Skipped: 0

Yes

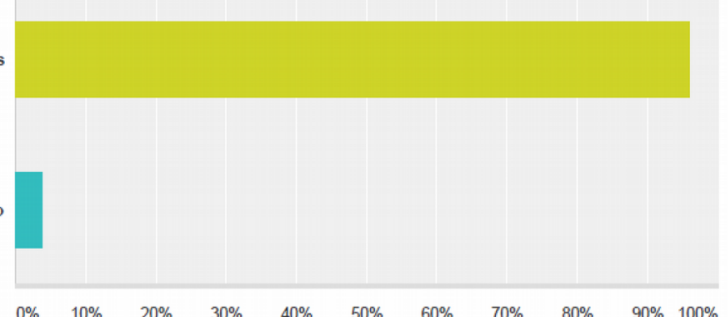

The examples and exercises given were Answered: 25 Skipped: 0

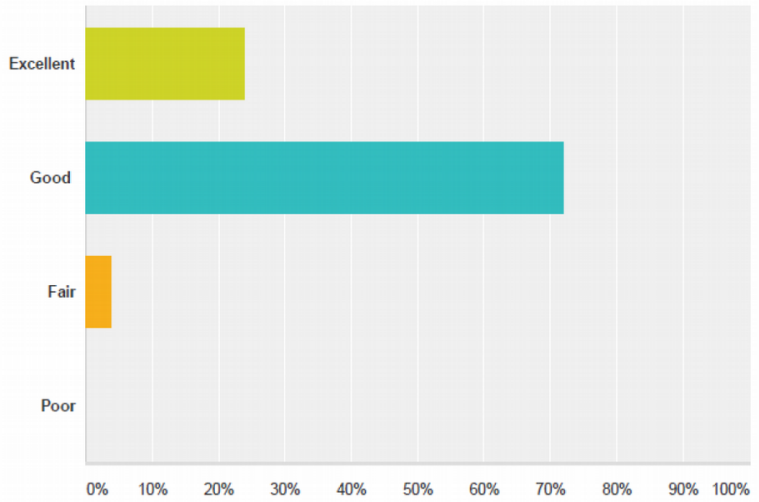

Activities in the class help me to check my level of understanding and to get help from teacher to have more clarity Answered: 25 Skipped: 0

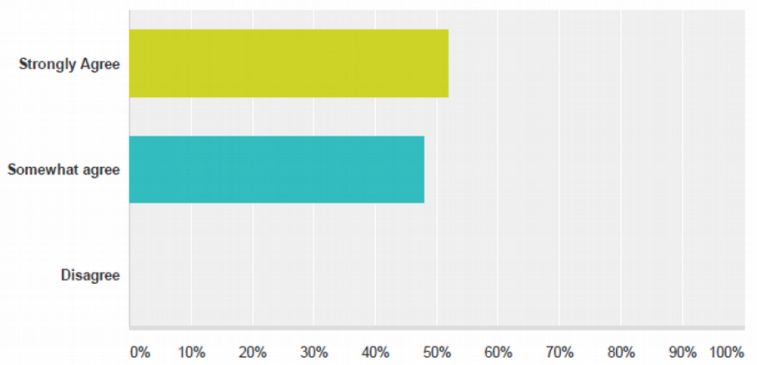

Class rooms are more effectively used rather than simply listening to the teacher Answered: 25 Skipped: 0

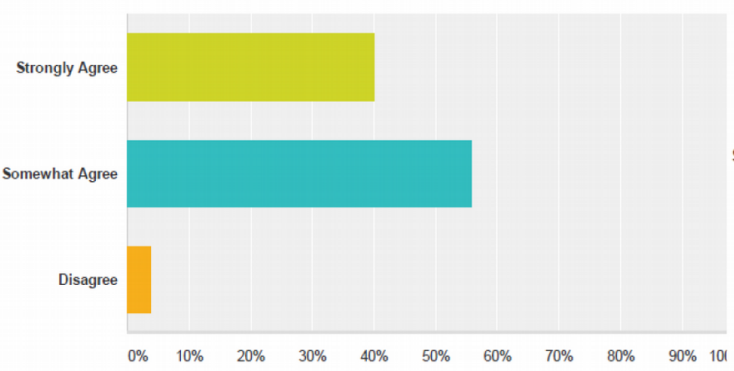

Lesson in general is clear and informative Answered: 25 Skipped: 0

Yes

No

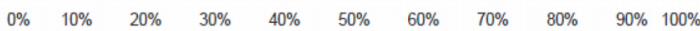

What did you like more about the lesson? Answered: 24 Skipped: 1

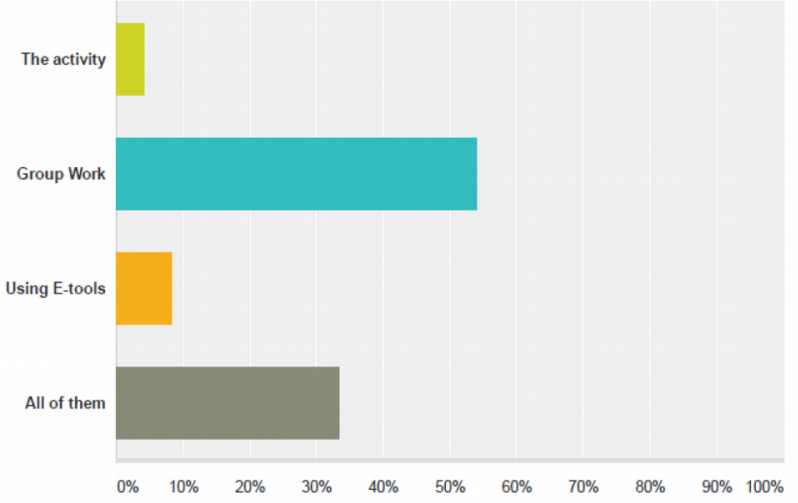

Preparing for the classes prior to the class and engaging in classroom activities gives me an ability to learn by myself (selflearning)

Answered: 25 Skipped: 0

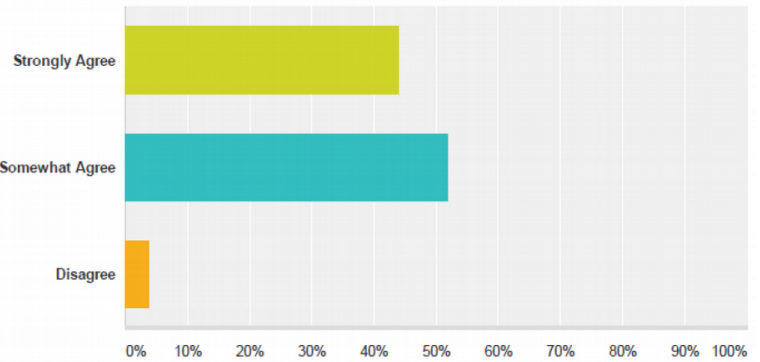

I am able to get help from my friends if I am stuck while doing activities

Answered: 24 Skipped: 1

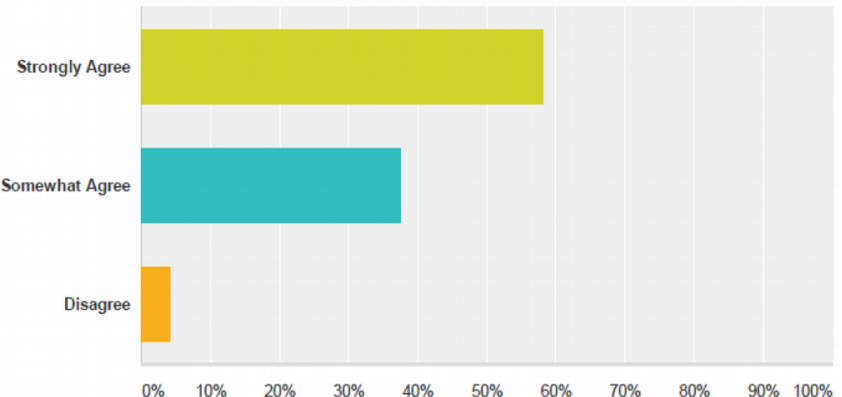

Figure 6. Example of students' feedback on classroom activities 


\section{Conclusions and Recommendations}

This paper aimed to determine the effectiveness of flipped teaching and active learning in Project Management module for undergraduate students in civil engineering and discussed the impacts into students' learning experience. On the one hand, students' feedback revealed that the use of flipped learning method and active learning improved their performance and enhance their learning. On the other hand, they were interested with the classroom activities which engaged them deeply with the learning process. In conclusion, the flipped learning method supporting with active learning approaches resulting in an effective and deep learning process.

As a part of continues improvement, students in the coming semester will be involved in finding and selecting their final projects as a part of Project-Based Learning. Furthermore, students will be encouraged to conduct peer observation to collect feedback on their works. It is also recommended that students have to obtain hands-on experience managing real projects where they have to deal with real clients and perform the project processes learnt in class.

\section{Declaration of Conflicting Interests}

The author declared no potential conflicts of interest with respect to the research, authorship, and/or publication of this article.

\section{Funding}

The author received no financial support for the research, authorship, and/or publication of this article.

\section{References}

Anney, V.N., \& Mosha, M.A. (2015). Student's Plagiarisms in Higher Learning Institutions in the Era of Improved Internet Access: Case Study of Developing Countries. Journal of Education for Business, 6(13), 203-216.

Arnold-Garza, S. (2014). The flipped classroom teaching model and its use for information literacy instruction. Communications in Information Literacy, 8(1), 7-22. https://doi.org/10.15760/comminfolit.2014.8.1.161

Bergmann, J., \& Sams, A. (2013). Flip your students' learning. Educational leadership, 70(6), 16-20.

Bhattacharjee, J. (2015). Constructivist Approach to Learning an Effective Approach of Teaching Learning. International Research Journal of Interdisciplinary \& Multidisciplinary Studies (IRJIMS), I(VI), 65-74.

Biggs, J., \& Tang, C. (2011). Teaching for Quality Learning at University (4th ed.). Buckingham: The Society for Research into Higher Education \& Open University Press.

Bishop, J., \& Verleger, M. (2013). The Flipped Classroom: A Survey of the Research. Presented at the $120^{\text {th }}$ ASEE Annual Conference and Exposition. Atlanta, USA.

Bradbury, N.A. (2016). Attention span during lectures: 8 seconds, 10 minutes, or more?. Advances in Physiology Education, 40, 509-513. https://doi.org/10.1152/advan.00109.2016

Collingbourne, L., \& Seah, W.K.G. (2015). Teaching Project Management using a Real-World Group Project. Presented at the IEEE Frontiers in Education Conference (FIE), Texas, USA.

https://doi.org/10.1109/FIE.2015.7344301

Fry, H., Ketteridge S., \& Marshall, S. (2009). A Handbook for Teacbing and Learning in Higher Education Enhancing Academic Practice. London, UK: Routledge Taylor and France Group.

Gary, W., \& Min, Y. (2017). Using ICT to Facilitate Instant and Asynchronous Feedback for Students' Learning Engagement and Improvements. Emerging Practices in Scholarship of Learning and Teaching in a Digital Era, 289-309. 
Hussein, B.A. (2015). A Blended Learning Approach to Teaching Project Management: A Model for Active Participation and Involvement: Insights from Norway. Education Sciences, 5(2), 104-125. https://doi.org/10.3390/educsci5020104

Kalimullina, A.M., Yungbludb, V.T., \& Khodyreva, E.A. (2016). Characteristic Features of Innovation Project Management Aimed at University Human Resource Development. International Journal of Environmental \& Science Education, 11(9), 2237-2253.

Kim, J.A., Heo, H.J., \& Lee, H. (2015). Effectiveness of Flipped learning in Project Management Class. International Journal of Software Engineering and Its Applications, 9(2), 41-46.

Kistner, S., Rakoczy, K., Otto, B., Klieme, E., \& Büttner, G. (2015). Teaching learning strategies: The role of instructional context and teacher beliefs. Journal for Educational Research Online, 7(1), 176-197.

Kolås, L. (2015). Application of interactive videos in education. 2015 International Conference on Information Technology Based Higher Education and Training (ITHET) (1-6). Lisbon. https:/ / doi.org/10.1109/ITHET.2015.7218037

Kolesnikova, I.V. (2016). Combined Teaching Method: An Experimental Study. World Journal of Education, 6(6), 51-59. https://doi.org/10.5430/wje.v6n6p51

Kulasegaram, K., \& Rangachari, P.K. (2018). Beyond "formative": assessments to enrich student learning. Advances in Physiology Education, 42(1), 5-14. https://doi.org/10.1152/advan.00122.2017

Lalima, \& Dangwal, K.L., (2017). Blended Learning: An Innovative Approach. Universal Journal of Educational Research, 5(1), 129-136. https://doi.org/10.13189/ujer.2017.050116

Lim, L.L. (2014). A Case Study on Peer-Teaching. Open Journal of Social Sciences, 2(8), 35-40. https://doi.org/10.4236/jss.2014.28006

O'Flaherty, J., \& Phillips, C. (2015). The use of flipped classrooms in higher education: A scoping review. Internet and Higher Education, 25, 85-95. https://doi.org/10.1016/j.iheduc.2015.02.002

Othman, A., Pislaru, C., \& Impes, A. (2014). An Improved Lab Skills Model and its Application to the Computer Science Course at Omar Al-Mukhtar University, Libya. Yükseköğretim Dergisi, 4(1), 32-43. https://doi.org/10.2399/yod.14.004

Ramazani, J., \& Jergeas, G. (2015). Project managers and the journey from good to great: The benefits of investment in project management training and education. International Journal of Project Management, 33(1), 41-52. https://doi.org/10.1016/j.ijproman.2014.03.012

Roach T. (2014). Student perceptions toward flipped learning: New methods to increase interaction and active learning in economics. International Review of Economics Education, 17, 74-84.

https://doi.org/10.1016/j.iree.2014.08.003

Shabani, K., Khatib, M., \& Ebadi, S. (2010). Vygotsky's Zone of Proximal Development: Instructional Implications and Teachers' Professional Development. Canadian Center of Science and Education, 3(4), 237-248. https://doi.org/10.5539/elt.v3n4p237

Slomanson, W.R. (2014). Blended Learning: A Flipped Classroom Experiment. Journal of Legal Education, 64(1), 93-102.

Published by OmniaScience (www.omniascience.com)

Journal of Technology and Science Education, 2019 (www.jotse.org)

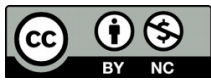

Article's contents are provided on an Attribution-Non Commercial 4.0 Creative commons International License. Readers are allowed to copy, distribute and communicate article's contents, provided the author's and JOTSE journal's names are included. It must not be used for commercial purposes. To see the complete licence contents, please visit https://creativecommons.org/licenses/by-nc/4.0/. 